\title{
Stage IV Malignant Mediastinal Germ Cell Tumor
}

National Cancer Institute

\section{Source}

National Cancer Institute. Stage IV Malignant Mediastinal Germ Cell Tumor. NCI

Thesaurus. Code C146852.

Tumor with distant metastasis. (WHO Classification of Tumors of the Lung, Pleura,

Thymus and Heart, 2015) 